\title{
The Influence of Accounting Information Quality on Trade Credit with Inventory Liquidation Cost as Moderating Variable
}

\author{
Nanda Fito Mela* Adhitya Agri Putra \\ Lecturer at the Faculty of Economics and Business, University of Riau, \\ Campus Binawidya KM.12,5 Simpang Baru, Tampan, Pekanbaru, Riau, 28296
}

\begin{abstract}
This research is aimed to examine (1) effect of accounting information quality on trade credit, (2) moderating role of inventory liquidation cost on the effect of accounting information quality on trade credit. Research sample are 122 manufacture companies listed in Indonesian Stock Exchange 2013-2016. Data analysis uses multiple regression test. Results show that accounting information quality has effect on trade credit usage. It indicates that suppliers advantages of free of information asymmetric, direct involvement to company's business activities, and higher recovery rate of payment failure makes suppliers are less likely to use accounting information to evaluate company's credit worthiness; further, it leads to high trade credit fund resource used by company with low accounting information quality. Inventory liquidation cost moderates the effect of accounting information quality on trade credit usage. It indicates that suppliers will give trade credit for company with low accounting information quality if inventory liquidation cost is low.
\end{abstract}

Keywords: Accounting Information Quality, Trade Credit, Inventory Liquidation Cost

DOI: $10.7176 /$ RJFA/10-12-14

Publication date:June $30^{\text {th }} 2019$

\section{Introduction}

One of accounting information user is capital provider; such as investor or creditor. They use accounting information to evaluate company's worthiness if company is worth to get their funds. The funds can be equity capital (investor fund resource), debt capital (bank and financial institution fund resource), and trade credit (supplier fund resource).

Important role of accounting information leads to the important of accounting information quality. High quality accounting information helps capital provider evaluate company accurately. Bhattacharya et al.(2013) states that High quality accounting information can reduces information asymmetric, so capital provider can count on accounting information as important source of information in company risk evaluation and monitoring.

Previous researches too much focus on relationship between information quality and equity and debt capital, such as Bharathet al.(2008) that examines information quality on cost of debt, Francis et al.(2004, 2005)and Garcia Lara et al.(2011)that examines information quality on cost of debt and equity, Biddle and Hilary (2006)that shows company with low information quality use internal fund resource. In Indonesia, Moh.Nasihet al.(2016)find that earnings quality and information asymmetric have effect on cost of equity.

Chen et al.(2017)states that there is no researches that examines information quality and trade credit directly until 2017. This research focuses on trade credit because it has important role as fund resource to support core business activities directly. Wilson and Summers (2003) also states that trade credit is important external resource fund for companies in emerging country, such as Indonesia. Geand Qiu(2007)also support the argument that trade credit has important role in emerging economics because limited access of resource fund from banks.

In Indonesian Stock Exchange (IDX), average of manufacture companies trade credit increases from 20132017. Based on this research data proceed (2019), there is increasing of trade credit for manufacture companies in IDX from Rp. 687 billionin 2013 to Rp. 897 billion in 2017. It indicates that, in Indonesia,there is big demand of trade credit to support manufacture companies business activities.

Chen et al.(2017)states that existence of information asymmetric makes bank and financial institution so much depends on accounting information.Investor and debt provider need more accounting information than suppliers. Suppliershave more advantages than financial institution and bank, because suppliers do not depend on accounting information only. Suppliers can get information directly through daily business transactions(Chen et al., 2017). Even there are some financial institutions have access to private information, suppliers can get private information fast and low cost, because it is enough to see company normal business activities (Petersen and Rajan, 1997).

Companies with high information quality have better access on equity and debt financing(Chen et al., 2017), while companies with low information quality have difficult access on equity and debt financing. It makes companies with low accounting information quality tend to use trade credit from suppliers. The lower accounting information quality, the higher trade credit usage is.

Chen et al.(2017)explains that there is still possibility of information asymmetric between suppliersand companies. It happens because supplier is smaller than companies or because new suppliers that do not know yet 
about companies industry. For example, case of Hewlett-Packard (HP). HP is printer supplier. HP is failed to fulfills market target because its executives failed to assess if printer demand reflects market demand or reseller demand(Chen et al., 2017). In this case, supplierstend to use accounting information to evaluate credit worthiness of companies. If suppliers cannot assess credit worthiness because of low information quality, then supplierswill assess their claims when companies really have financial difficulties to pay trade credit. Chen et al. (2017) states that when companies in financial difficulties condition, suppliershave right to take back (inventory liquidation) the supplied goods. Supplierswill assess inventory liquidation cost to evaluate credit worthiness of companies. If there are many supplied goods in company's inventory, then inventory liquidation cost for suppliers is low. Low inventory liquidation cost makes suppliers ignore accounting information quality in provide trade credit.

Chen et al.(2017)finds that accounting information quality has negative effect on trade credit. It indicates that lower information quality followed by increasing of trade credit usage. The negative effect is strengthened when inventory liquidation cost is low (Chen et al., 2017). Based on above explanation, this research is aimed to examine (1) effect of accounting information quality on trade credit, (2) moderating role of inventory liquidation cost on the effect of accounting information quality on trade credit.

This research is expected give additional literature for regulator and accounting standard setter that accounting information needs are different for each capital provider. Chen et al.(2017) finds that suppliers have less needs for accounting information quality than bank and financial institution. Regulator and standard setter can consider about different needs of accounting information in determining potential cost and benefit of each accounting information user when formulates financial reporting standard.

\section{Literature Review}

\subsection{Agency Theory}

Jensen and Meckling(1976) explains agency relationship as contract between principal and agent where principal gives authority to agent to manage companies activities. Focus of agency theory is agency conflict of these two parties because of interest difference. Agency conflict relates to information asymmetric where principal have less information about company than agent because principal do not involve directly to daily business activities.

In context offunding resource, principal is capital provider and agent is company's management. As responsibility of management, company issues financial statement. Financial statement provides accounting information for capital provider to evaluate management performance. In order to make accurate evaluation, accounting information user needs high quality information. Compare to bank and financial institution that do not involve directly to daily business activities of company, suppliers involve directly to daily business activities of company and have less information asymmetric and need less high quality accounting information.

\subsection{Signaling Theory}

Signaling theory is aimed to compares between high quality and low quality companies (Kirmani and Rao, 2000), include in its accounting information. Different with agency theory, signaling theory focuses on decreases information asymmetric where companies give signal to external parties about its quality. Connelyet al.(2011) states that main focus of signaling theory is private information providing by companies. In context of funding resource, companies use accounting information to give signal of credit worthiness. High quality accounting information has important role in signaling process.

\subsection{Accounting Information Quality}

Accounting information is provided as financial statement (Weygandt et al., 2014). Core objective of financial statement is to give information about financial position, performance, and cash flow of companies and will be used to make economic decision making by financial statement users (Ikatan-Akuntan-Indonesia, 2013, para. 7 PSAK 1). In order to make accurate economic decision, financial statement has to provide high quality information.

One of basic assumption of financial reporting is accrual. Accrual bases more superior than cash bases in evaluation of performance and predicting future performance. One of description about accounting information quality is accrual quality. Accrual quality measures accurateness in predicting future cash flow (Dechow and Schrand, 2004). High accrual quality shows that management can use right accounting policy and estimation to provide accurate cash flow prediction.

\subsection{Trade Credit}

Trade credit reported as account payable in financial statement. Trade credit is amount that has to be paid by management tosuppliers as implication of credit goods or services purchasing. Trade credit is credit purchasing transaction where it does not need signed formal document of company obligation to suppliers. 


\subsection{Inventory Liquidation Cost}

Suppliers as one of capital provider have risk as well. If companies have financial difficulties, then there will be problem of trade credit payment to suppliers. Chen et al.(2017) states that suppliers have priority in fulfillment of their rights when companies have financial difficulties, which is inventory liquidation.

Inventory liquidation is aimed to cover suppliers lost of trade credit payment. It will be taken and sold back by suppliers. In inventory liquidation, suppliers have to cover inventory liquidation cost. Inventory liquidation cost pictures supplied inventory availability, such as raw material. If supplied inventory availability is high, then inventory liquidation cost is low, and otherwise. Inventory liquidation cost is one consideraion by suppliers to give trade credit for companies.

\subsection{Hypotheses Development}

Suppliers have superior position in facing information asymmetric because they involve directly with companies' activities (Petersen and Rajan, 1997). First advantage, suppliers have strong position in companies' supply chain. Suppliers can give threat by stopping goods supply to companies if there is increasing of payment failure. The threat is effective when companies only have little supplier options. It has implication immediately to companies' operation. In the other hand, threat by financial institution/bank to stop funding stream do not immediately affect to companies' operation.

Second advantage, suppliersdo not get loss easily when payment failure is exist, because they have higher recovery level than financial institution/bank. When company experience financial difficulties, suppliers can directly use their right to take supplied goods back (Ravert, 2006). Chen et al.(2017)states that suppliers' right will be fulfilled first when company experience financial difficulties. Supplierscan use their business network to sell their goods back.

Third advantage, suppliershave benefits to get information about company. Petersen and Rajan(1997)states that suppliersmore often to oversee company than other financial institution, so that supplierscan assess company's condition based on quantity and period of credit purchasing. For example, company's inability to pay trade credit earlier in discount period gives suppliers signal of bad credit worthiness (Petersen and Rajan, 1997).

On companies' side, high accounting information quality gives better access to debt and decrease trade credit. High accounting information quality helps debt provider to assess risk because company is transparent. Otherwise, trade credit usage does increase if accounting information quality is low because company have limited access to debt fund resource. It indicates that the lower accounting information quality, the higher trade credit will be. Based on above explanation, first hypothesis is as followed.

\section{H1: Accounting information quality has effect on trade credit usage}

There is possibility that supplier still need accounting information to forecast and assess credit demand and risk. Beside case of Hewlett-Packard that has been explained, financial problem of Sears company become focus of suppliersregarding to transparency of financial statement information (Chen et al., 2017). Zimmerman and Eder (2012)reports that after CIT Group Inc. stop supplying goods to Sears, other suppliersof Sears more focus on Sears financial statement, but they fails to evaluate Sears because limited access of Sears financial statement. Previous researches explain that company that "seems" transparent and worth to get credit only use trade credit form small suppliers (Klapper et al., 2012; Murfin and Njoroge, 2015). Increasing of trade credit from big supplierswill not happen because company does not increase accounting information quality.

One of suppliers' advantage that has been explained before is higher recovery level than financial institution/bank. When company experience financial difficulties, suppliers can directly use their right to take supplied goods back (Ravert, 2006). It can be benefits for suppliers if inventory liquidation (taking supplied goods back) cost is low. In such condition, suppliersdo not need a lot of information to assess credit risk because supplierscan immediately take company's inventory back to cover their losses. When inventory liquidation cost is high, suppliersare more depend on accounting information quality in credit risk evaluation. Suppliersare more likely to accept credit purchasing from company with low inventory liquidation cost. Chen et al.(2017)finds that negative effect of accounting information quality on trade credit is stronger for company with low inventory liquidation cost. Based on above explanation, first hypothesis is as followed.

\section{H2: Inventory liquidation cost moderates the effect of accounting information quality has effect on trade credit usage}

\section{Research Results and Discussion}

\subsection{Sample}

Research sample are manufacture companies listed in Indonesian Stock Exchange in 2013-2016. Selection of manufacture companies as sample because there is increasing of trade credit usage from 2013 to 2017. Result of sample selection is as followed. 
Table 1. Research Sample

\begin{tabular}{|l|l|}
\hline Criteria & Company \\
\hline Manufacture companies listed in Indonesian Stock Exchange 2013-2016 & 128 \\
\hline Incomplete data & 2 \\
\hline Change financial reporting period & 4 \\
\hline Total & $\mathbf{1 2 2}$ \\
\hline Total year-companies for 2013-2016 & $\mathbf{4 8 8}$ \\
\hline
\end{tabular}

\subsection{Variable and Operational Definition}

Dependent variable in this research is trade credit usage. It is calculated as followed (Chen et al., 2017).

Trade credit usage $=\frac{\text { trade credit }}{\text { book value of total assets }}$ (1)

Independent variable is accounting information quality. It is measured by accrual quality. Consideration accrual quality as accounting information quality measurement because it shows how close non cash component to cash flow that can be used to evaluate payment ability of company by suppliers.(Dechow and Dichev, 2002).

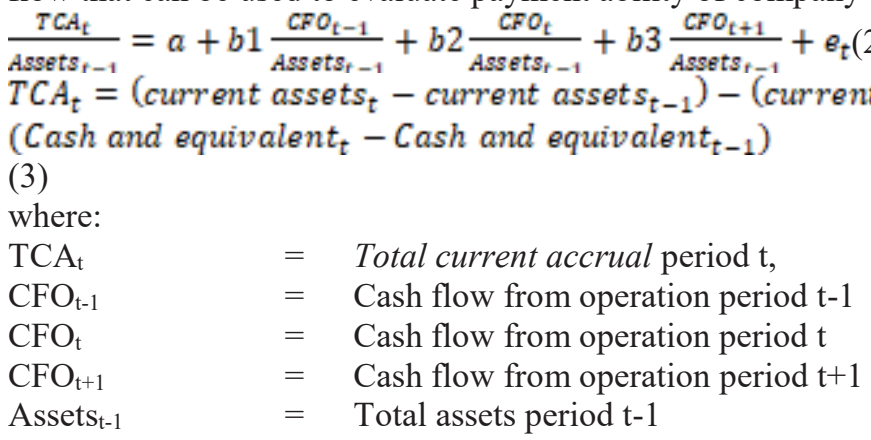

Accrual quality is measured from absolute value of $e_{t}$ from equation (2) multiple by -1(Chen et al., 2017). The higher accrual quality, the higher accounting information quality will be.

Moderation variable is inventory liquidation cost. It is measured as followed (Chen et al., 2017).

Inventory liquidation cost $=-\frac{\text { raw material }}{\text { book value of total assets }}$ (4)

Control variables are current ratio, cash hold, company's size, and market value of equity to total assets. Current ratio shows company ability to fulfill current liabilities, includes trade credit, by using current assets. Suppliers will give trade credit for company with high current ratio (Chen et al., 2017). Current ratio is measured by current assets divided by current liabilities.Cash hold shows available cash and equivalent in company. The higher available cash and equivalent, the lower failure risk, so supplierswill give more trade credit for company (Chen et al., 2017). Cash hold is measured by cash and equivalent divided by total assets. Company's size shows how big company is. Big company has better access to stock market and other financial institution, so company is less likely to use trade credit as fund resource(Chen et al., 2017). Company's size is measured by logarithm of total assets.Market value of equity to assets shows company's growth. Growing company uses more trade credit because there is increasing of business activities (Chen et al., 2017). Market value of equity to assets is measured by stock price divided by book value of total assets per share.

\subsection{Analysis Model}

Hypotheses test is done by regression test. In order to ensure free bias of regression model, this research tests classical assumptions as well; which are normality, multicollinearity, autocorrelation, and heterocedasticity.

Regression model is as followed.

$Y=a+b_{1} X_{1}+b_{2} X_{1} Z+b_{3} Z+b_{4} X_{2}+b_{5} X_{3}+b_{6} X_{4}+b_{7} X_{5}+e$

Keterangan:

$\mathrm{Y}=$ Trade credit

$\mathrm{X}_{1}=$ Accounting information quality

$\mathrm{Z}=$ Inventory liquidation cost

$\mathrm{X}_{2}=$ Current Ratio

$\mathrm{X}_{3} \quad=$ Cash Hold

$\mathrm{X}_{4}=$ Company's size

$\mathrm{X}_{5}=$ Market Value of Equity to Total Assets

a $=$ Constant

$\mathrm{b}_{1}-\mathrm{b}_{7}=$ Coefficient 


\section{Result and Discussion}

\subsection{Descriptive Statistics}

Table 2. Descriptive Statistics

\begin{tabular}{lrrrrr}
\hline & N & Minimum & Maximum & Mean & Std. Deviation \\
\hline Trade Credit & 488 & 0.0000 & 0.6881 & 0.111177 & 0.0981825 \\
Accounting Quality & 488 & -6.0838 & -0.0004 & -0.096638 & 0.3630380 \\
Inventory Liquidation Cost & 488 & -0.44 & 0.00 & -0.0772 & 0.08177 \\
Current Ratio & 488 & 0.0140 & 464.9844 & 3.871952 & 24.1088200 \\
Cash hold & 488 & 0.0004 & 0.6315 & 0.088108 & 0.1073321 \\
Size & 488 & 10.56 & 14.42 & 12.3082 & 0.70064 \\
Market value of Equity to Assets & 488 & 0.03 & 17.95 & 1.1572 & 2.17668 \\
\hline
\end{tabular}

Source: proceed data, 2019

Table 2 shows that based on 488 samples, average of trade credit usage is 0.111177 with its deviation 0.0981825 . The lowest trade credit usage is 0.0000 ; while the highest is 0.6881 . Average of accounting quality is -0.096638 with its deviation 0.3630380 . The lowest quality is -6.0838 ; while the highest is -0.0004 . Average of inventory liquidation cost is -0.0772 with its deviation 0.08177 . The lowest inventory liquidation cost is -0.044 ; while the highest is 0.00 .

\subsection{Classical Assumptions Test}

Table 3. Classical Assumptions Test

\begin{tabular}{lll}
\hline Test & Result & Notes \\
\hline Kolmogorov-Smirjnov $(\mathrm{N}=488)$ & Significance value $<0.05$ & Data dose not distributed normally \\
\hline Kolmogorov-Smirjnov $(\mathrm{N}=438)$ & Significance value $>0.05$ & Data distributed normally \\
\hline Tolerance and VIF & Tolerance $>0.1 ;$ VIF $<10$ & Free of multicollinearity problem \\
\hline Glejser & Significance value $>0.05$ & Free of heterocedasticity problem \\
\hline Durbin-Watson & DW $=1.928$ & Free of autocorrelation problem \\
\hline
\end{tabular}

Source: proceed data, 2019

Table 3 shows that Kolmogorov-Smirjnov test for 488 samples have result as data dose not distributed normally. Normality problem is, then, solved by cutting 50 extreme data. Kolmogorov-Smirjnov test for 438 samples shows that data distributed normally. Multicollinearity test shows tolerance value is above 0.1 and VIF value below 10; which is indicates that this research is free of multicollinearity problem. Glejser test shows that significance value above 0.005; which is indicates that this research is free of heterocedasticity problem. DurbinWatson test shows that DW value is 1.928 (between "dU" and "4-dU"); which is indicates that this research is free of autocorrelation problem.

\subsection{Hypotheses test}

Table 4. Hypotheses test

\begin{tabular}{lrrrr}
\hline & Coefficient & t-statistics & Significance & Notes \\
\hline Constant & 0.071 & & & \\
Accounting Quality & -0.025 & -2.491 & 0.013 & $\mathrm{H} 1$ accepted \\
Accounting Quality x Inventory Liquidation & 0.130 & 2.563 & 0.011 & $\mathrm{H} 2$ accepted \\
Cost & & & & \\
Inventory Liquidation Cost & 0.010 & 0.307 & 0.759 \\
Current Ratio & 0.000 & -1.007 & 0.315 \\
Cash hold & 0.059 & 2.303 & 0.022 \\
Size & 0.000 & 0.098 & 0.922 \\
Market value of Equity to Assets & 0.002 & 1.554 & 0.121 \\
\hline
\end{tabular}

Sig. $F=0.000$

Adjusted $\mathrm{R}^{2}=0.060$

Dependent Variable $=$ Trade Credit Usage

Source: proceed data, 2019

Table 4 shows that accounting information quality has coefficient value -0.025 with significance value 0.013 (below 0.05). It shows that first hypothesis is accepted. Information accounting quality has effect on trade credit usage. Variable interaction between accounting information quality and inventory liquidation cost has coefficient value 0.130 with significance value 0.011 (below 0.05 ). It shows that second hypothesis is accepted. Inventory liquidation cost moderates the effect of accounting information quality on trade credit usage. 


\subsection{Discussion}

Information accounting quality has effect on trade credit usage. It is consistent with Chen et al.(2017) that finds decreasing of accounting information quality limits access of equity and debt funds and leads to trade credit usage as fund resource. Suppliers advantages; such as free of information asymmetric, direct involvement to company's business activities, and higher recovery rate of payment failure than other financial institution and banks; makes suppliers are less likely to use accounting information to evaluate company's credit worthiness. It leads to high trade credit fund resource used by company with low accounting information quality.

Inventory liquidation cost moderates the effect of accounting information quality on trade credit usage. It is consistent with Chen et al.(2017) that finds suppliers will give trade credit for company with low accounting information quality if inventory liquidation cost is low. There is possibility that information asymmetric exists between company and suppliers; especially for new and small suppliers. In this case, these suppliers need more high accounting information quality to assess company's credit worthiness. Suppliers can give high trade credit for company with low accounting information quality if suppliers' potential losses can be recovered by low cost inventory liquidation. In the other hand, suppliers will use more accounting information to assess company's credit worthiness if inventory liquidation cost is high.

\subsection{Conclusion}

This research is aimed to examine (1) effect of accounting information quality on trade credit, (2) moderating role of inventory liquidation cost on the effect of accounting information quality on trade credit. Results show that accounting information quality has effect on trade credit usage. It indicates that suppliers advantages of free of information asymmetric, direct involvement to company's business activities, and higher recovery rate of payment failure makes suppliers are less likely to use accounting information to evaluate company's credit worthiness; further, it leads to high trade credit fund resource used by company with low accounting information quality. Inventory liquidation cost moderates the effect of accounting information quality on trade credit usage. It indicates that suppliers will give trade credit for company with low accounting information quality if inventory liquidation cost is low.

Limitation of this research is this research does not consider suppliers' characteristic; such as size or supply tenure, because of limitation access of data. Future research is expected to consider suppliers' characteristic in the analysis.

\section{References}

Bharath, S.T., Sunder, J. and Sunder, S. (2008), “Accounting Quality and Debt Contracting”, The Accounting Review, Vol. 83 No. 1, pp. 154-174.

Bhattacharya, N.H., Desai, H. and Venkataraman, K. (2013), "Earning Quality and Information Asymmetry: Evidence from Trading Costs", Contemporary Accounting Research, Vol. 30 No. 2, pp. 482-516.

Biddle, G. and Hilary, G. (2006), "Accounting Quality and Firm-Level Capital Investment", The Accounting Review, Vol. 81 No. 5, pp. 963-982.

Chen, D., Liu, M., Ma, T. and Martin, X. (2017), “Accounting Quality and Trade Credit”, Accounting Horizons, Vol. 31 No. 3, pp. 69-83.

Connelly, B.L., Certo, S.T., Ireland, R.D. and Reutzel, C.R. (2011), "Signaling Theory: A Review and Assessment", Journal of Management2, Vol. 3 No. 1, pp. 39-67.

Dechow, P. and Schrand, C. (2004), Earnings Quality, Research Foundation of CFA Institute Monograph, USA.

Dechow, P.M. and Dichev, I.D. (2002), "The Quality of Accruals and Earnings", The Accounting Review, Vol. 77 No. Supplement, pp. 35-59.

Francis, J., LaFond, R., Olsson, P. and Schipper, K. (2005), "The market pricing of accruals quality", Journal of Accounting and Economics, Vol. 39 No. 2, pp. 295-327.

Francis, J., LaFond, R., Olsson, P.M. and Schipper, K. (2004), "Costs of Equity and Earnings Attributes", The Accounting Review, Vol. 79 No. 4, pp. 967-1010.

Garcia Lara, J.M., Garcia Osma, B. and Penalva, F. (2011), "Conditional Conservatism and Cost of Capital", Review of Accounting Studies, Vol. 16 No. 2, pp. 247-271.

Ge, Y. and Qiu, J. (2007), "Financial Development, Bank Discrimination and Trade Credit", Journal of Banking \& Finance, Vol. 31 No. 2, pp. 513-530.

Ikatan-Akuntan-Indonesia. (2013), PSAK 1: Penyajian Laporan Keuangan, IAI, Jakarta.

Jensen, M.C. and Meckling, W.H. (1976), "Theory of The Firm: Managerial Behaviour, Agency Cost and Ownership Structure", Journal of Financial Economics, Vol. 3 No. 4, pp. 305-360.

Kirmani, A. and Rao, A.R. (2000), "No pain, no gain: A critical review of the literature on signaling unobservable product quality", Journal of Marketing, Vol. 64 No. 2, pp. 66-79.

Klapper, L., Laeven, L. and Rajan, R. (2012), “Trade Credit Contracts”, Review of Financial Studies, Vol. 25 No. 3, pp. 838-867. 
Moh.Nasih, Komalasari, P.T. and Moh.Madyan. (2016), "Hubungan Antara Kualitas Laba, Asimetri Informasi, dan Biaya Modal Ekuitas: Pengujian Analisis Jalur”, Jurnal Akuntansi Dan Keuangan Indonesia, Vol. 13 No. 2, pp. 221-242.

Murfin, J. and Njoroge, K. (2015), “The Implicit Costs of Trade Credit Borrowing by Large Firm”, Review of Financial Studies, Vol. 28 No. 1, pp. 112-145.

Petersen, M. and Rajan, R. (1997), "Trade Credit: Theories and Evidence”, Review of Financial Studies, Vol. 10 No. 3, pp. 661-691.

Ravert, G. (2006), A Vendor's Guide to Bankruptcy, McDermott Will \& Emery LLP, New York.

Weygandt, J.J., Kimmel, P.D. and Kieso, D.E. (2014), Accounting Principle, 12th ed., Jhon Willey \& Son. Inc, New Jersey.

Wilson, N. and Summers, B. (2003), "Trade credit terms offered by small firms: Survey Evidence and Empirical Analysis", Journal of Business Finance \& Accounting, Vol. 29 No. 3-4, pp. 317-351.

Zimmerman, A. and Eder, S. (2012), "Sears Seeks to Calm Nerves", available at: https://www.wsj.com/articles/SB10001424052970203721704577157192111664960 (accessed 3 November 2018). 